\title{
THE EVALUATION OF OCCUPANTS' BEHAVIOUR AND PREFERENCES IN OFFICE BUILDINGS IN GHANA
}

\author{
C. Koranteng \\ Department of Architecture, \\ Kwame Nkrumah University of Science and Technology, Kumasi, Ghana \\ Email: christiankoranteng@yahoo.co.uk
}

\begin{abstract}
Over a period of one year, five office buildings in Ghana have been studied and the occupants were interviewed to assess the operation and accessibility of system and system controls at their working environment. In all, 64 occupants were interviewed. The results show that occupants in office buildings have a strong urge to operate windows, even in air-conditioned buildings. Satisfaction in office environment was found to correlate with the flexibility of building systems, system controls and personalisation of workspace. In addition, to increase the efficiency of building systems, occupants need to be trained in the proper use of the facilities available at their workspaces. The results of the evaluation serve to contribute to the process of refinement and improvement in office buildings.
\end{abstract}

Keywords: Occupants, Operation, Accessibility, Building Systems, Perception

\section{INTRODUCTION}

The availability, operation and accessibility of systems and system controls are key elements in indoor environment, which must be controlled to achieve comfort. Comfort and satisfaction are however not all the time achievable due to the complexity of building systems and their controls. This is the reason why user interactions do not necessarily lead to the desired conditions, given the relevant technical properties of any buildings' environmental systems (Loftness et al., 1995). Besides, user actions in office buildings are mainly an attempt to avoid discomfort, and they have effects on energy performance. When indoor conditions become unpleasant, occupants tend to use the available building systems (windows, fans, airconditioners, shades, etc.) in order to create satisfying indoor conditions (Nicol and Roaf, 2005). Moreover, the energy implications of these actions are mostly not considered. To some extent, the building elements may not be energy efficient and the problem is worsened by negative energy conscious behaviour (Mahdavi et al., 2007). In an extensive study of naturally ventilated buildings in a number of countries, Nicol (2001) found out that in European offices, a temperature of $22^{\circ} \mathrm{C}$ led to $50 \%$ opening of windows, which increased to $80 \%$ when the outdoor temperature rose to $33^{\circ} \mathrm{C}$. He concluded that there is a strong relationship between temperature and the operation of win- 


\section{$65 \quad$ Koranteng}

dows in all countries. However, Rijal et al. (2008) found out that interaction with windows increases at an outdoor temperature of $28.1^{\circ} \mathrm{C}$ in a study in Pakistan. Furthermore, the opening and closing of windows occurred when building occupants arrive or leave their workspaces and usually, windows are closed at the end of the day (Herkel et al., 2005). Mahdavi et al. (2007) concluded that the operation of shades in office buildings in Vienna, Austria, was as a result of solar radiation and the position of the sun in relation to the façades. Also, the shades on northern façades were used less than on the southern side and occupants operated the shades in order to reduce glare on their computer screens. Additionally, shades are usually fully raised or lowered (Sutter et al., 2006).

The more comfortable and satisfied occupants are, the higher the elements of personalisation at workspaces. Personalisation is seen through the unique arrangement of diverse and personal office elements (e.g., plants and photos) by employees at workspaces. Occupants over the years also develop a sense of what an ideal working space should look like and they tend to improve their environment whenever possible. A higher level of workspace personalisation has the tendency to increase satisfaction, comfort, interpersonal relationships and productivity.

The study of user behaviour, views and perceptions on building controls and functionality shows that the improvement of building design and performance (satisfaction, preference, thermal comfort, and energy efficiency) of office buildings is essential.

In this paper, a study on the performance evaluation of five office buildings in Kumasi over a 12 months period is presented. The thermal conditions (temperature and relative humidity) prevailing in the offices were monitored. Additionally, the perceptions of the occupants were evaluated in terms of operation and accessibility of systems, system controls, and preferred organization of workspaces.

\section{APPROACH}

Due to budgetary constraints, monitoring infrastructure dedicated toward obtaining more detailed and reliable micro-climatic data could not be used at each building's location. Thus, 20 data loggers (Ocr, 2008) were applied to observe air temperature and relative humidity in and around the buildings. The financial restriction was the reason for selecting only five prototype buildings having different orientations and environmental control systems. Four sensors (one measuring outdoor and three indoor) were consequently used to record environmental conditions in each building.

\section{(i) Buildings}

Five office buildings (College of Architecture and Planning Administration Block (CAP), Centre for Collaborative Research (KCR), Angel Administration Centre (ANG), Royal Plaza (ROY) and Community Development Centre (DCD) in Kumasi, Capital of Ashanti Region of Ghana) were selected for the studies. These buildings are representative of the majority of existing low-rise office buildings and house different functions (university offices, private companies, municipal offices, etc.). The applied cooling systems typically involve split air -conditioning units. A general description of the buildings is summarized in Table 1 .

\section{(ii) Interviews}

Following the long term study (12 months) of the thermal performance and observations of people's interaction with the environmental control systems of the selected office buildings, a number of occupants in each building were interviewed. In order to achieve accurate results on the users' assessment of both systems control options and prevailing indoor conditions, a benchmark of $60 \%$ of the occupants needed to be interviewed. The chosen benchmark is related to studies on thermal comfort, which state that irrespective of installed systems and due to biological variance, establishing a condition that satisfies every occupant is unlikely to be achievable (a dissatisfaction value of about $10 \%$ of occupants has been proven) (Loftness 
et al., 1995; Koranteng et al., 2009; and Fanger, 1973).

In all, 64 occupants from the five office buildings (75\% in CAP, $79 \%$ in $\mathrm{KCR}, 88 \%$ in $\mathrm{ANG}$, $83 \%$ in ROY and $90 \%$ in DCD) responded to the interviews. General information on the interviewees is presented in Table 2 . The respondents answered a comprehensive questionnaire based on the under listed areas: a) Profile of respondent;

b) Building control systems (operation and accessibility of systems and system controls); and

c) Preferred organization of workspaces.

The occupants' perceptions and evaluations were based on long term aggregate opinions on indoor climate and building control systems.

Table 1: General Description of the Office Buildings

\begin{tabular}{|c|c|c|c|c|c|}
\hline Building Code & CAP & KCR & ROY & ANG & DCD \\
\hline Function & $\begin{array}{l}\text { University } \\
\text { Building }\end{array}$ & NGO building & $\begin{array}{l}\text { Construction } \\
\text { company }\end{array}$ & $\begin{array}{l}\text { Private organi- } \\
\text { zation }\end{array}$ & $\begin{array}{l}\text { Community } \\
\text { building }\end{array}$ \\
\hline Location & KNUST & KNUST & Ahodwo & Bantama & Suame \\
\hline Office type & $\begin{array}{l}\text { Single, double } \\
\text { triple }\end{array}$ & $\begin{array}{l}\text { Single, double } \\
\text { open plan }\end{array}$ & $\begin{array}{l}\text { Single, open } \\
\text { plan }\end{array}$ & $\begin{array}{l}\text { Single, double, } \\
\text { triple }\end{array}$ & $\begin{array}{l}\text { Single, double, } \\
\text { triple }\end{array}$ \\
\hline $\begin{array}{l}\text { Office orienta- } \\
\text { tion }\end{array}$ & North & North & South west & West & South east \\
\hline $\begin{array}{l}\text { Thermal con- } \\
\text { trols }\end{array}$ & Mixed mode* & $\begin{array}{l}\text { Air- } \\
\text { conditioned }\end{array}$ & $\begin{array}{l}\text { Air- } \\
\text { conditioned }\end{array}$ & $\begin{array}{l}\text { Air- } \\
\text { conditioned }\end{array}$ & \\
\hline $\begin{array}{l}\text { Lighting con- } \\
\text { trols }\end{array}$ & $\begin{array}{l}\text { Manually con- } \\
\text { trolled }\end{array}$ & $\begin{array}{l}\text { Manually con- } \\
\text { trolled }\end{array}$ & $\begin{array}{l}\text { Manually con- } \\
\text { trolled }\end{array}$ & $\begin{array}{l}\text { Manually con- } \\
\text { trolled }\end{array}$ & $\begin{array}{l}\text { Manually con- } \\
\text { trolled }\end{array}$ \\
\hline Shades & $\begin{array}{l}\text { External } \\
\text { (fixed), inter- } \\
\text { nal, manually } \\
\text { controlled }\end{array}$ & $\begin{array}{l}\text { Internal, manu- } \\
\text { ally controlled }\end{array}$ & $\begin{array}{l}\text { Internal, manu- } \\
\text { ally controlled }\end{array}$ & $\begin{array}{l}\text { Internal, manu- } \\
\text { ally controlled }\end{array}$ & $\begin{array}{l}\text { Internal, manu- } \\
\text { ally controlled }\end{array}$ \\
\hline Windows & Operable & Operable & $\begin{array}{l}\text { Limited oper- } \\
\text { ability }\end{array}$ & Operable & Operable \\
\hline
\end{tabular}

*Mixed mode: Air-conditioned and naturally ventilated thermal controls 


\section{Koranteng}

Table 2: General Information on the Respondents

\begin{tabular}{|c|c|c|c|c|c|c|}
\hline Building & & CAP & KCR & ROY & ANG & DCD \\
\hline Number of respondents & & 24 & 10 & 10 & 10 & 10 \\
\hline \multirow[t]{2}{*}{ Gender [\%] } & Female & 21 & 60 & 40 & 60 & 70 \\
\hline & Male & 79 & 40 & 60 & 40 & 30 \\
\hline \multirow[t]{5}{*}{ Age [\%] } & $<25$ years & 4 & 20 & 30 & 10 & 0 \\
\hline & 25-35 years & 29 & 60 & 20 & 50 & 20 \\
\hline & $36-45$ years & 25 & 0 & 40 & 0 & 30 \\
\hline & $46-55$ years & 33 & 0 & 10 & 30 & 40 \\
\hline & $>55$ years & 9 & 20 & 0 & 10 & 10 \\
\hline \multirow{5}{*}{$\begin{array}{l}\text { Working hours per } \\
\text { week [\%] (self assessment) }\end{array}$} & 0-30 hours & 4 & 0 & 10 & 0 & 0 \\
\hline & $31-40$ hours & 71 & 60 & 60 & 50 & 90 \\
\hline & 41-50 hours & 13 & 30 & 20 & 30 & 10 \\
\hline & 51-60 hours & 8 & 10 & 10 & 20 & 0 \\
\hline & $>60$ hours & 4 & 0 & 0 & 0 & 0 \\
\hline \multirow{5}{*}{$\begin{array}{l}\text { Presence at the workstation } \\
\text { [\%] (self assessment) }\end{array}$} & $0-30$ hours & 25 & 40 & 40 & 60 & 20 \\
\hline & $31-40$ hours & 67 & 50 & 60 & 30 & 80 \\
\hline & 41-50 hours & 8 & 10 & 0 & 0 & 0 \\
\hline & 51-60 hours & 0 & 0 & 0 & 0 & 0 \\
\hline & $>60$ hours & 0 & 0 & 0 & 10 & 0 \\
\hline \multirow{7}{*}{$\begin{array}{l}\text { Work performed on computer } \\
{[\%] \text { (self assessment) }}\end{array}$} & $0-10 \%$ & 9 & 10 & 30 & 20 & 100 \\
\hline & $11-20 \%$ & 9 & 0 & 0 & 0 & 0 \\
\hline & $21-30 \%$ & 0 & 0 & 0 & 0 & 0 \\
\hline & $31-40 \%$ & 4 & 0 & 10 & 0 & 0 \\
\hline & $41-50 \%$ & 0 & 20 & 0 & 10 & 0 \\
\hline & $51-60 \%$ & 17 & 10 & 0 & 10 & 0 \\
\hline & $>60 \%$ & 61 & 60 & 60 & 60 & 0 \\
\hline
\end{tabular}


(iii) Long-term measurements within the framework (long term measurements of climatic data, evaluation of indoor environment, calibration and simulation of building models) of a study on the thermal performance of office buildings in Ghana (Koranteng et al., 2009), air temperature and relative humidity values were measured both inside and outside the buildings over a period of 12 months. In all, 897,580 data points (temperature and relative humidity values) were gathered. Data loggers were used in the one year data acquisition period. The monitoring period was from September 2007 to $\mathrm{Au}-$ gust 2008. The accuracy of the respective sensors is given in Table 3 .

Table 3: Accuracy of the sensors

\begin{tabular}{lll}
\hline Sensor & Range & Error \\
\hline $\begin{array}{l}\text { Air tempera- } \\
\text { ture }\end{array}$ & -20 to $70{ }^{\circ} \mathrm{C}$ & $\pm 0.4{ }^{\circ} \mathrm{C}$ \\
$\begin{array}{l}\text { Relative hu- } \\
\text { midity }\end{array}$ & 5 to $95 \%$ & $\pm 3 \%$ \\
\hline
\end{tabular}

Source: OCR (2008)

\section{(iv) Statistical analysis of data}

To a large extent, the data gathered was processed with Microsoft Excel, because of its high compatibility with a number of other applications. Other software applications used in the study were Greenline and Hoboware pro. Greenline was used to launch and download the files from the data loggers. The downloaded temperature and relative humidity values were screened in Hoboware pro software, after which the data points were exported to an MS Excel file. In MS Excel, the text files were imported, screened, and built together in monthly tables. Since the data recorded was in an interval of minutes, formulae sheets were generated to produce mean hourly values and the output values were graphed and analysed.
The outcome of the questionnaire based on the subjective opinion of the occupants of the office buildings were tabulated and graphed (mean and percentage values) in MS Excel.

\section{RESULTS}

The evaluation results are presented here with Fig. 1 showing the three-month mean working time indoor temperatures during the dry and rainy season. Fig. 2 demonstrates the percentage of occupants to whom the operation of windows and shades were important, whereas Fig. 3 shows occupants who had difficulty in the operation of windows and shades. Fig. 4 expresses in percentage those occupants who were not satisfied with the position of the airconditioner and fan in relation to the workspaces, and Fig. 5 those who had to negotiate with colleagues before operating building systems. In addition, Fig. 6 shows those to whom building systems were not easily accessible. Fig. 7 illustrates the percentage of occupants who were less satisfied with the possibility to ventilate and rarely/never had a morning flush before using the air-conditioner in the offices. Fig. 8 addresses the percentage of occupants who generally found the office climate to be poor. The mean yearly indoor temperatures prevailing in the buildings are also shown in Fig. 8. Fig. 9 shows the percentage of occupants to whom the effects of plants on indoor climate were important and those who were less satisfied with available possibilities of workspace personalisation (plants, photos, furniture, etc).

The average vote and rank of occupants in building CAP on features of an ideal working place is illustrated in Table 4. Table 5 shows the average vote and rank of improvement measures considered urgent in building CAP. Finally, Fig. 10 shows the vote on improvement measures considered most urgent by the occupants in all the buildings (CAP, KCR, ANG, ROY and DCD). 


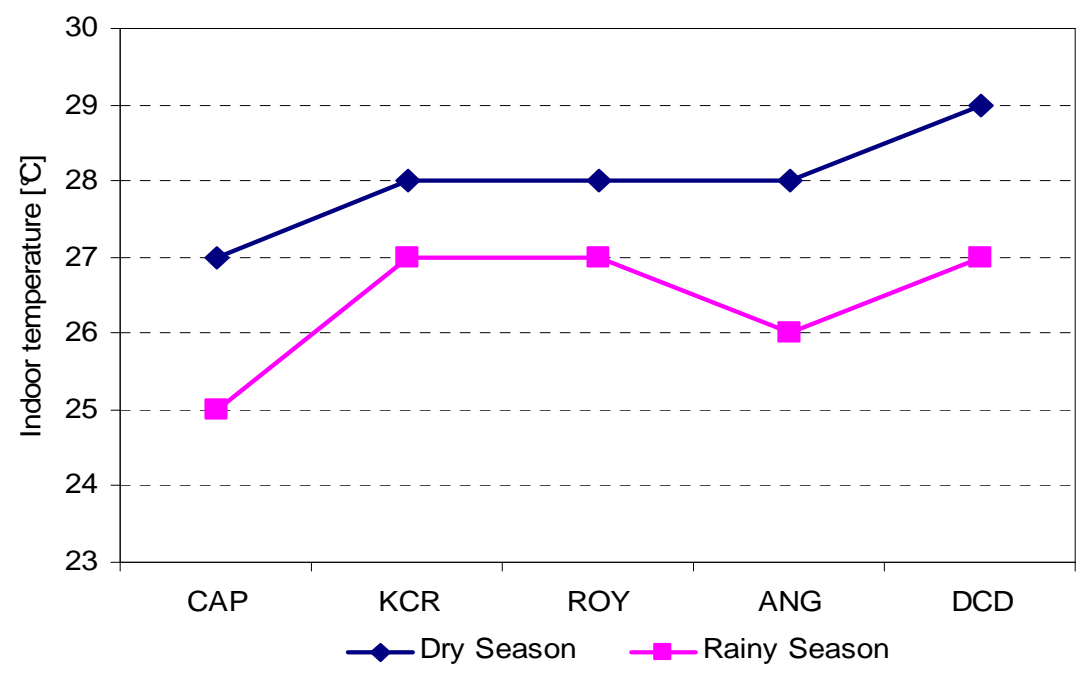

Fig.1: Three-month mean working time indoor temperature during the dry and rainy season

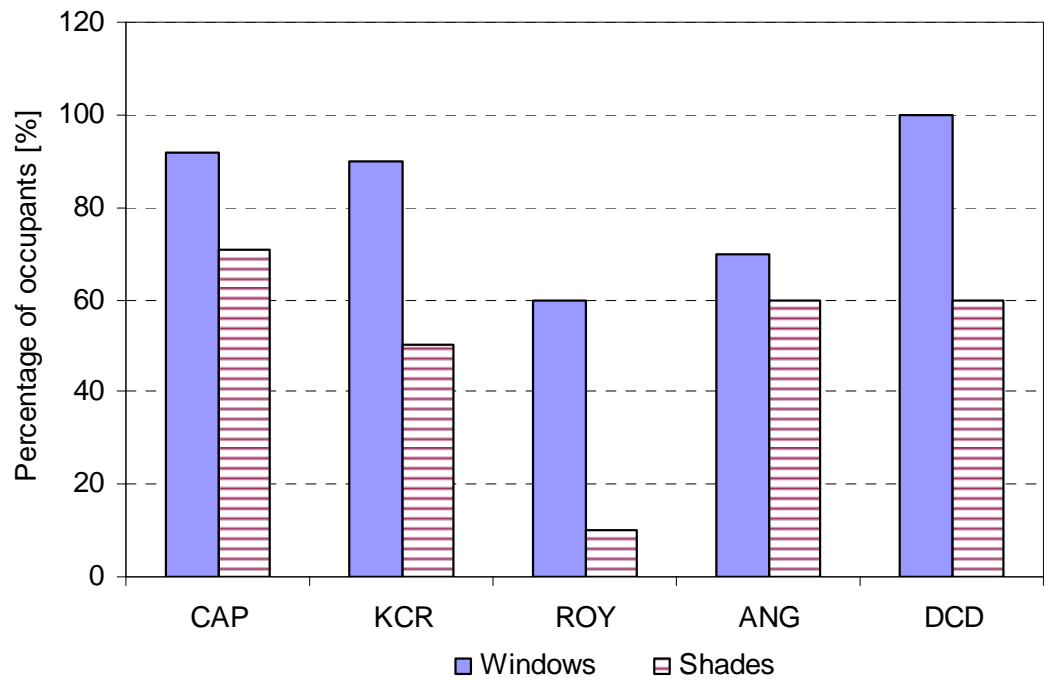

Fig.2: Percentage of occupants to whom the operation of windows and shades was important 


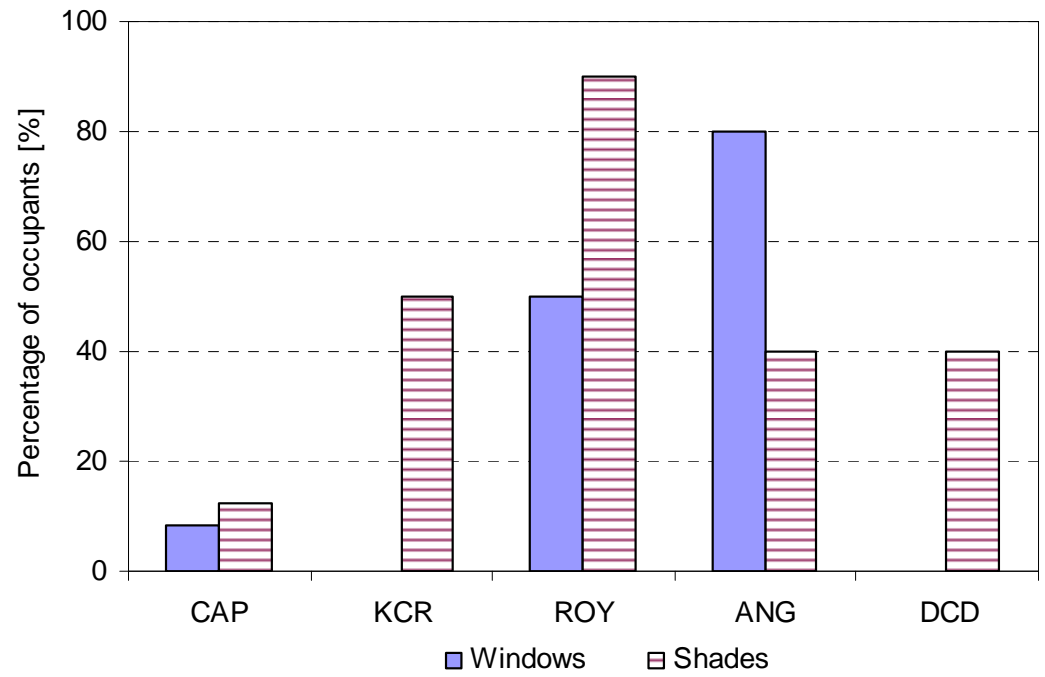

Fig.3: Percentage of occupants who had difficulty in the operation of windows and shades

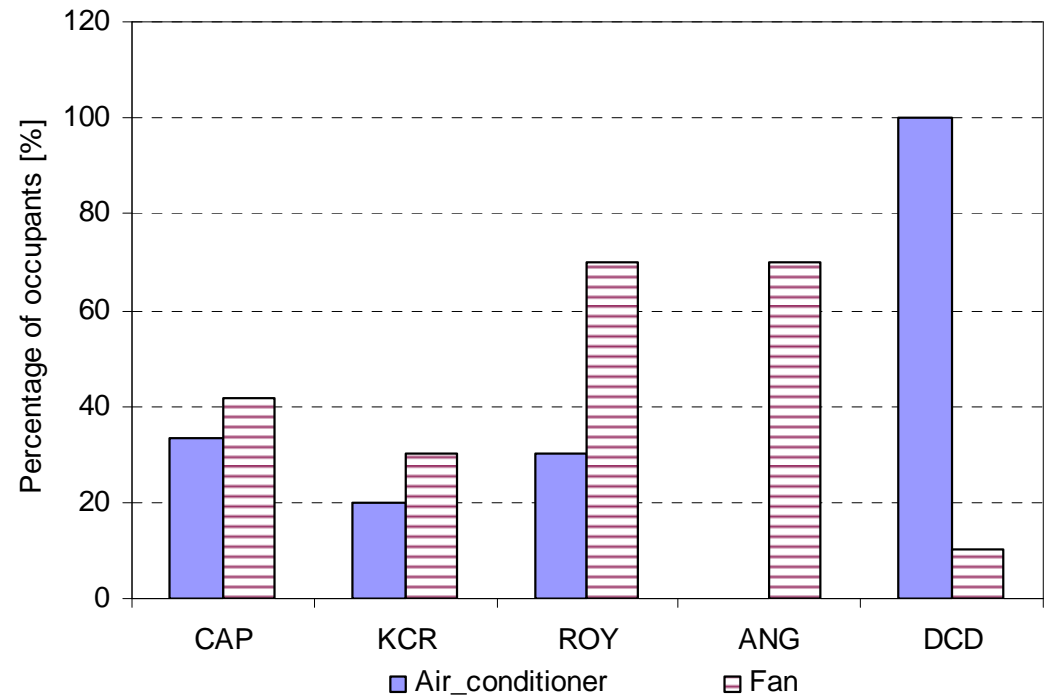

Fig.4: Percentage of occupants who were not satisfied with the availability and position of the air-conditioner and fan to workspace 


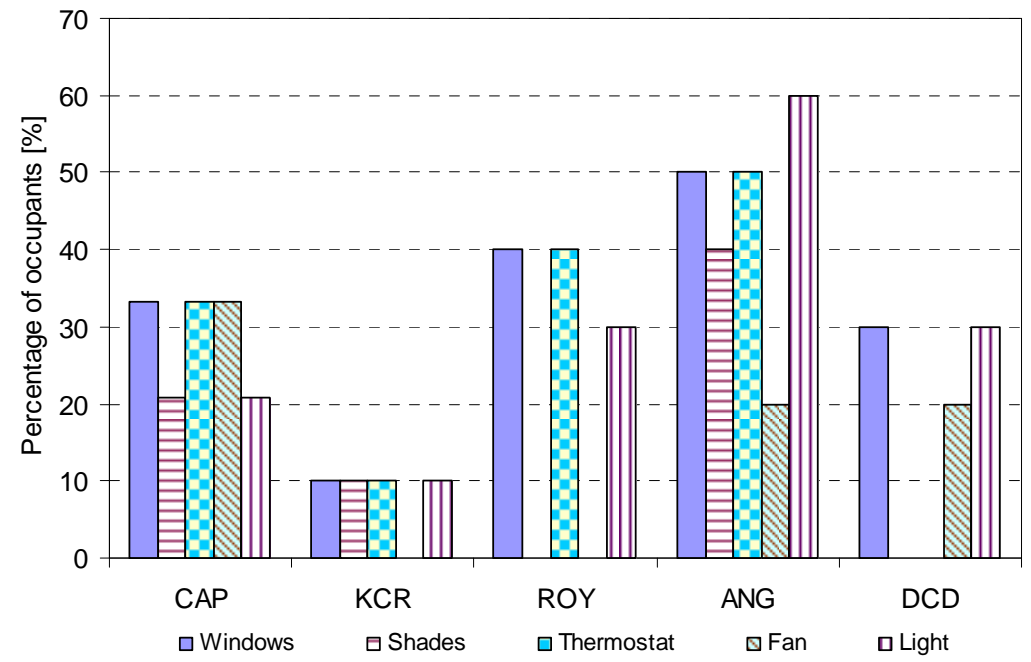

Fig.5: Percentage of occupants who had to negotiate with colleagues before operating building systems

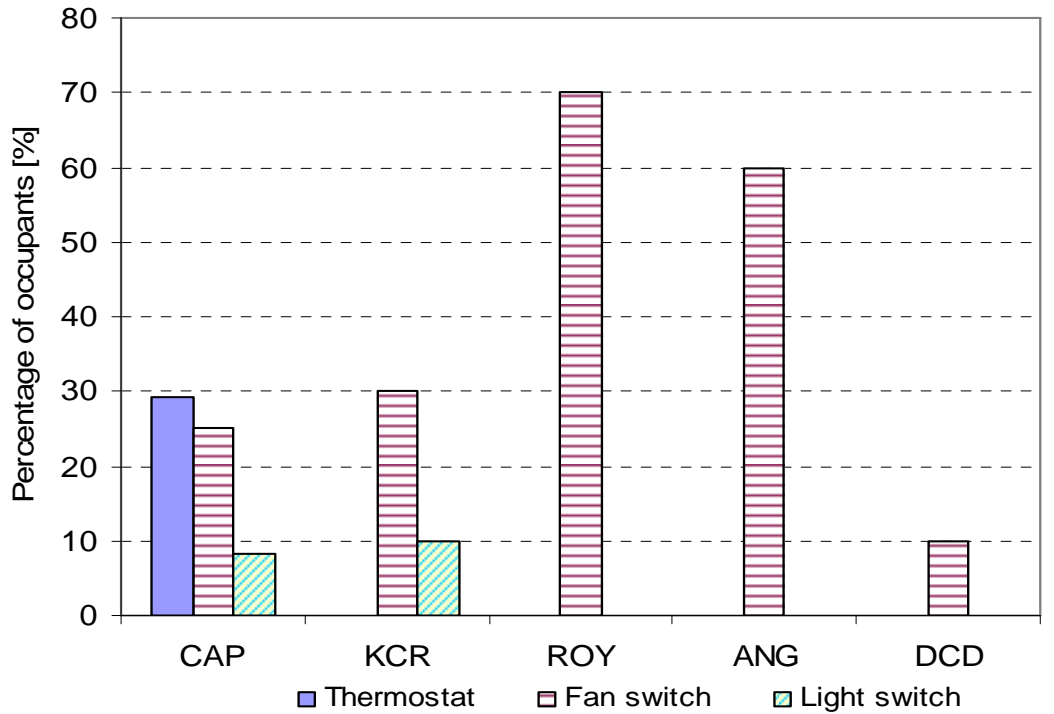

Fig.6: Percentage of occupants to whom building systems were not easily accessible 


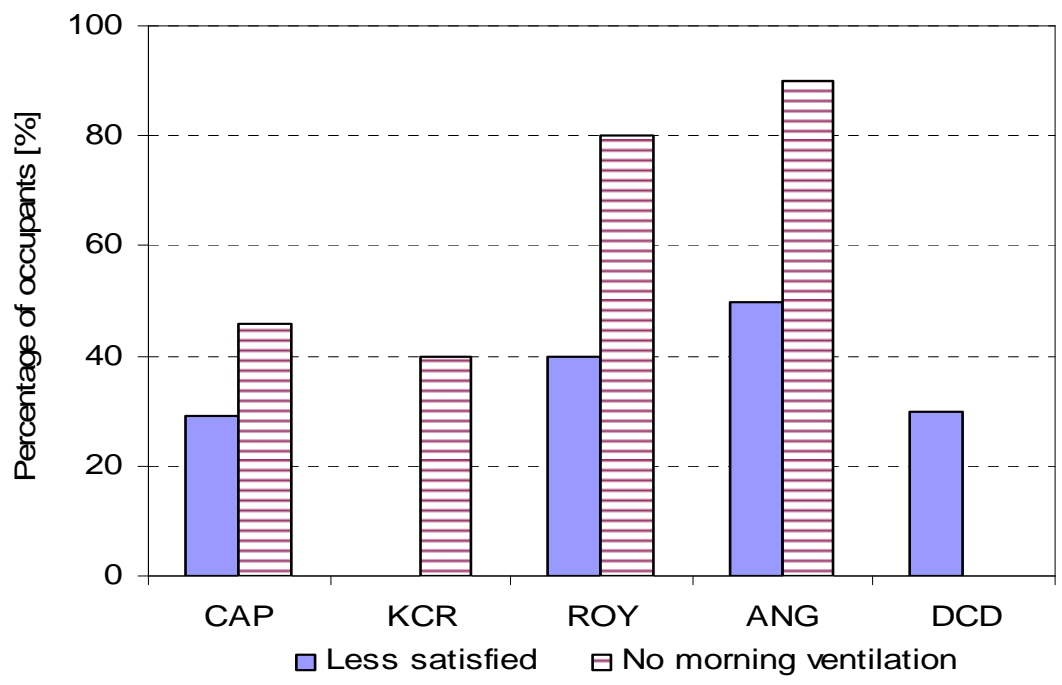

Fig.7: Percentage of occupants who were less satisfied with the possibility to ventilate and rarely/never had a morning flush before using the air-conditioner in their offices

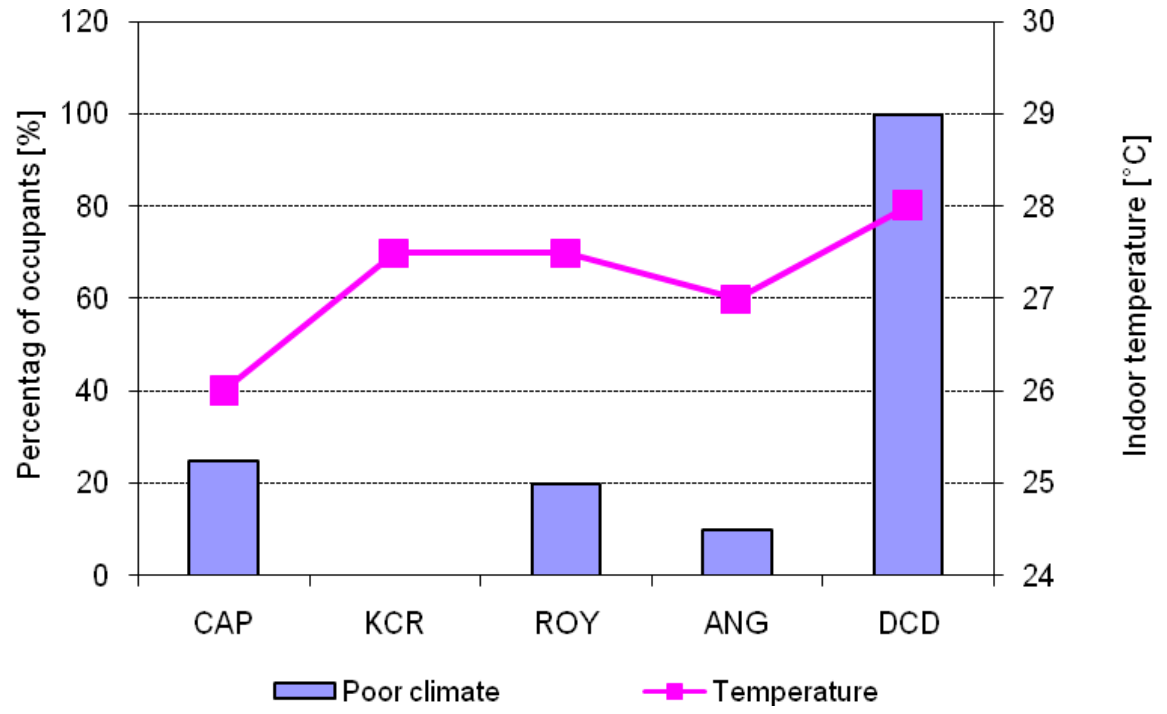

Fig.8: Percentage of occupants who generally found their office climate to be poor and the mean yearly indoor temperature 


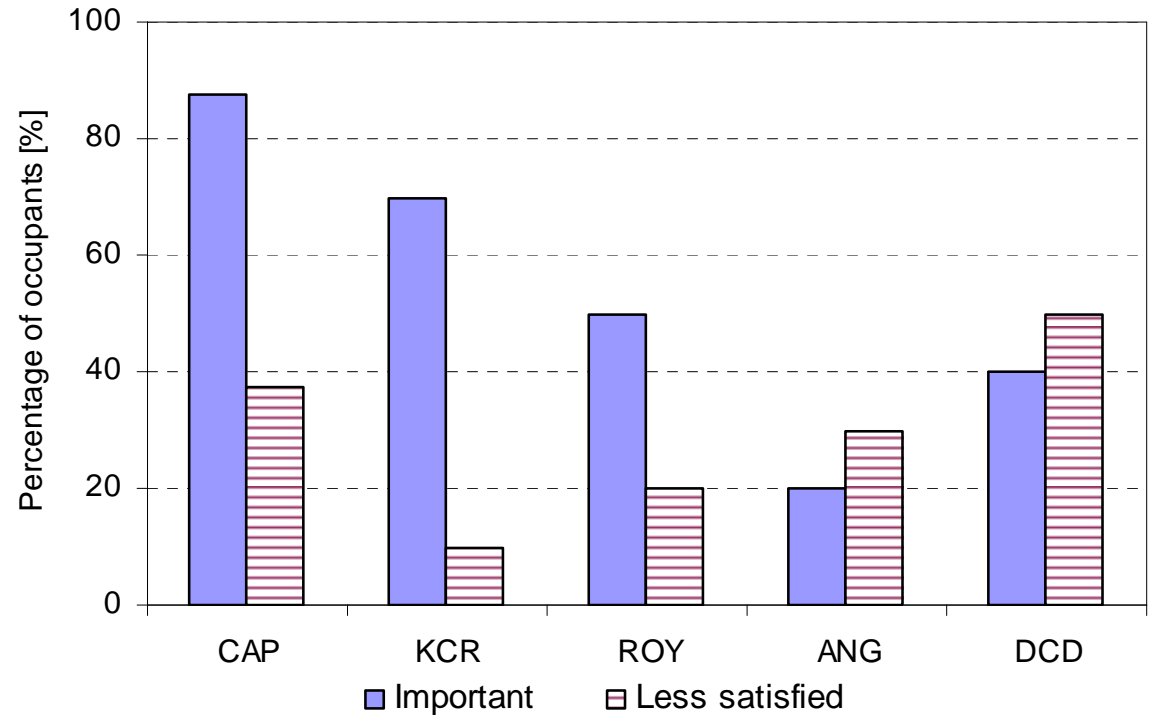

Fig.9: Percentage of occupants to whom the effects of plants on indoor climate were important and those who were less satisfied with available possibilities of workspace personalisation (plants, photos, furniture, etc.)

Table 4: The average vote and rank of occupants in building CAP on features of an ideal

\begin{tabular}{ll}
\hline Features Measures & $\begin{array}{l}\text { Vote and Rank on Important Features of } \\
\text { Ideal Working Place }\end{array}$ \\
\hline Air quality & 9 \\
Comfort of furnishings and dimensions of work- & 8 \\
station & 7 \\
Thermal comfort & 6 \\
Security against theft & 6 \\
Liberty to control your own work environment & 5 \\
Visual comfort (lighting/shades) & 4 \\
Acoustic and visual privacy & 4 \\
Acoustic comfort & 4 \\
Fire safety & 3 \\
Beauty/aesthetics of the building & 2 \\
\hline
\end{tabular}


Table 5: The average vote and rank of occupants in building CAP on improvement measures.

$\begin{array}{ll}\text { Features Measures } & \begin{array}{l}\text { Vote and Rank on Most Urgent Measures } \\ \text { Needing Improvement }\end{array}\end{array}$

Comfort of furnishings and dimensions of work9 station

Air quality

Security against theft

Thermal comfort

Visual comfort (lighting/shades)

Fire safety

Liberty to control your own work environment

Acoustic comfort

Acoustic and visual privacy

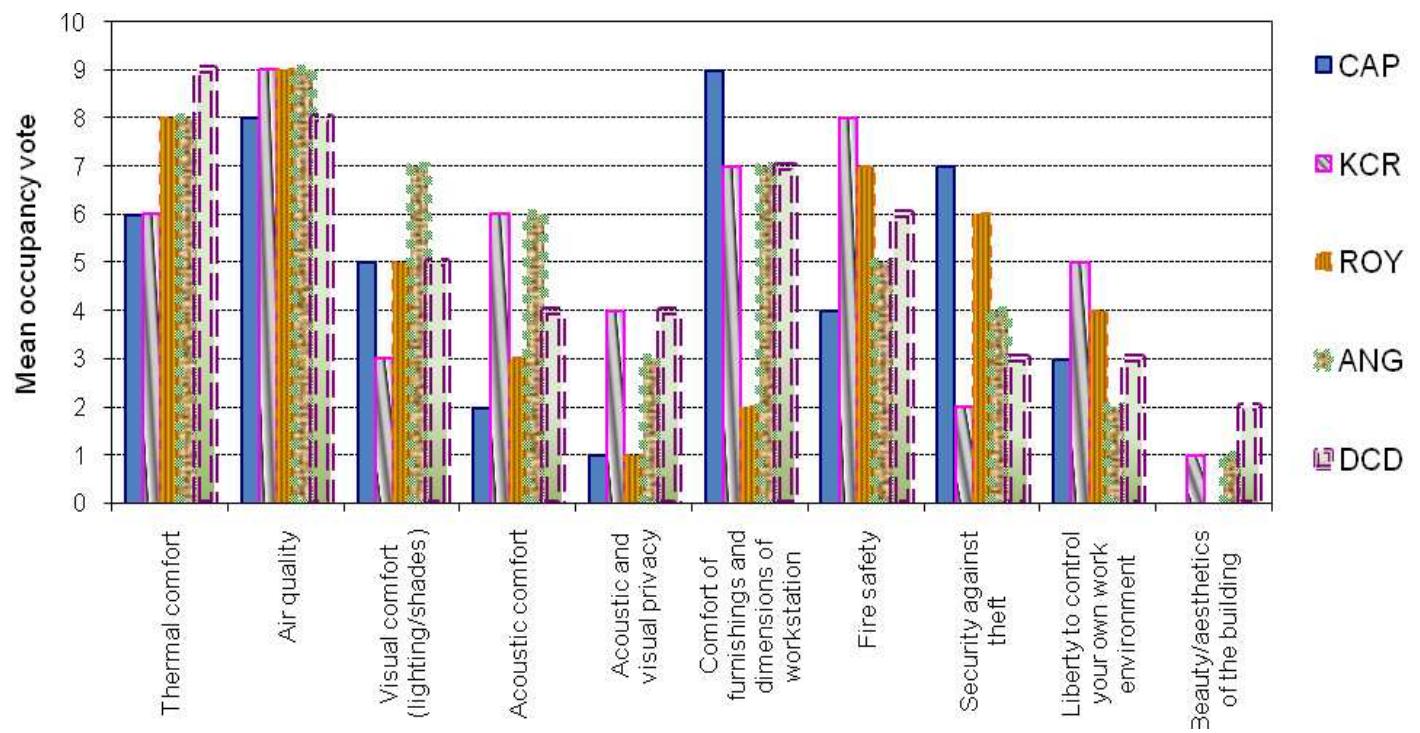

Fig.10: Vote on improvement measures considered most urgent by the occupants in all the buildings with vote 10 being the most important measure 


\section{DISCUSSION}

The results of the study provide important suggestions to the operation and accessibility of systems and system controls, and workspace personalization in office buildings that could serve as a contribution to the process of refinement and improvement of office buildings.

The behaviour of occupants and the operation of building systems to create a comfortable indoor environment are interrelated (Heerwagen, 2004). Over a period of one year, indoor environment parameters have been recorded and analysed. A three-month mean indoor temperature during the dry and rainy season gives an indication of the thermal environment in all five buildings (Fig. 1). At these temperatures, the body must react in order to balance itself with the thermal environment. The thermal balance is determined by the internal heat load and thermal exchange through conduction, convection, radiation and evaporation to attain comfort (Gut and Ackerknecht, 1993).

At CAP, an indoor temperature of $27^{\circ} \mathrm{C}$ was recorded, which reduced by $2^{\circ} \mathrm{C}$ during the rainy season. KCR and ROY had indoor temperatures of $28^{\circ} \mathrm{C}$ during the dry season and a reduction of 1 and $1-2^{\circ} \mathrm{C}$ during the rainy season respectively. The highest temperature was recorded at DCD with $29^{\circ} \mathrm{C}$ during the dry season and $27^{\circ} \mathrm{C}$ during the rainy season. The differences in the indoor temperatures were mainly due to aspects of the building form, orientation, shading and surrounding vegetation. Orientation affects indoor climate through solar radiation heating walls and rooms, and ventilation problems in relation to prevailing wind direction (Givoni, 1976). Other factors that affect indoor temperature and comfort are building systems (windows, shades, fans, lights, air-conditioners, etc.) and their operation by occupants to bring about preferable indoor conditions (Nicol and Roaf, 2005). Interestingly, the naturally ventilated building of DCD had a $27^{\circ} \mathrm{C}$ indoor temperature during the rainy season. The same temperature was recorded at KCR and ROY, which were air-conditioned buildings. To further reduce the indoor temperature from $27^{\circ} \mathrm{C}$ to $25^{\circ} \mathrm{C}$ as in CAP during the rainy season and at passive state, attention should be given to a good orientation, wind direction and a higher window to wall ratio (Lechner, 2001).

Moreover, $25 \%$ of the respondents in building CAP perceived the office climate to be poor (Fig. 8). The mean yearly indoor temperature was $26^{\circ} \mathrm{C}$, which was the lowest in all buildings under the study. This means that dissatisfaction with office climate was not due to thermal discomfort but rather due to the double and triple occupancy of the cramped workspaces and associated frictions. In addition, the effects of building systems, quality and efficiency of equipment were all possible issues that could have affected the perception on the office environment.

At KCR, no respondent found the office climate to be poor, even though a higher annual mean indoor temperature of $27.5^{\circ} \mathrm{C}$ was registered. At the same annual temperature of $27.5^{\circ}$ C, $20 \%$ of the respondents in ROY found the office climate to be poor. At ANG, $15 \%$ rated the indoor climate as poor. All respondents at DCD found the office climate to be poor. The naturally ventilated building of DCD was not optimally oriented and shaded. Environmental control systems were also not in the best condition and the problem was worsened by the dusty northeast trade winds during the dry season. The higher afternoon outdoor temperatures also affected the thermal conditions of the indoor environment. This calls for the installation of proper and efficient building systems to increase comfort and satisfaction. Other sustainable measures that could be practiced are shape and orientation to breezes, open plan interior and vertical airshafts to promote airflow, wing walls and overhangs in the direction of winds (Watson and Labs, 1983). The use of fans is also recommended since in related studies, this has been found to increase comfort by raising the evaporative potential of the skin, resulting in a physiological cooling sensation of up to $3^{\circ}$ 
C (Hyde, 2000)

Though the buildings studied have different window types, most occupants were of the opinion that it was important for them to operate the windows and shades (Fig. 2). For 82\% of all interviewees, it was important to be able to operate the windows. The importance attached to the operation of the shades was however $50 \%$ for all occupants under the study.

The difficulty in the operation of shades is presented in Fig. 3. For 50\% and $80 \%$ of the occupants at ROY and ANG, much difficulty was reported in the operation of windows whereas $50 \%$ and $90 \%$ had a lot of difficulty in the operation of shades at KCR and ROY respectively. The difficulties experienced were due in part to the malfunction and difficult accessibility of the shades. Generally, shading the exterior, interior, and surrounding areas of a structure is the first line of action to reduce the temperature build-up due to ambient air or solar incidence (Salmon, 1999), and these sustainable measures should be practiced. At DCD and in most of the office buildings, the impression gained was that building systems were not properly maintained. This caused increased dissatisfaction on the part of the occupants and the development of a lackadaisical attitude in the operation of shades was observed. The careless approach of occupants in the deployment of shades correlates with a study of office buildings in Austria by Mokamelkhah (2007).

The position of the fans and air conditioners was also a concern for the occupants (Fig. 4). Forty-one percent of the respondents were not fully satisfied with the positions of the building systems. It was observed that some occupants refused to use the air-conditioners because they were not satisfied with its position in relation to their workspaces. Others complained about health issues due to the position of the system. Dissatisfaction with the position of the fan was $44 \%$ on the average. This high expression of dissatisfaction could be due to workspaces situated too far from the fans or a malfunction, which was not attended to over a long period of time. Generally, the lack of information and difficulty in the operation of building systems and system controls reduced workspace satisfaction of respondents, as also reported by Mohammadi (2007).

In shared offices, workers had to negotiate before they could operate building systems. As high as $44 \%$ of workers from ANG had to undergo this operation process and $28 \%$ at CAP also negotiated before operating building systems (Fig. 5). In shared offices, the effect of negotiations about building system operation (windows, shades, fans, lights, air-conditioners, etc.) on the relationship among workers could not be statistically justified by this study, even though occupants sometimes reported minor tensions due to these kinds of negotiations. On the other hand, studies have shown that occupants in office buildings are not generally disturbed when they have to work in shared offices (Mokamelkhah, 2007).

Occupants also reported that some building systems were not easily accessible (Fig. 6). The non-accessibility of the thermostat was expressed by $29 \%$ of the respondents in CAP. This was because the air-conditioner regulator was in most cases a mounted switch on the wall, which was sometimes not easy to reach. Either it was near the head of the section or boxes were piled up in front of the switch making it difficult to access. Workspaces were in most of the cases far from the switch, especially the fan regulators and occupants felt lazy to get up every time to operate it.

Those who were less satisfied with the possibility to ventilate the offices were $30 \%$ on the average (Fig. 7). Reasons for dissatisfaction were mainly due to positions, availability and state of the building systems.

Generally, the more comfortable occupants are in their work environment, the more they tend to personalize their workspace. The majority of the interviewees saw the effects of plants on 


\section{$77 \quad$ Koranteng}

indoor climate in a positive way. The higher percentages from CAP, KCR and ROY could be linked to the green surroundings and therefore, generally rating the effects of plants higher (Fig. 9). In the less green environments, averagely, only $30 \%$ of the occupants had an affirmative opinion on the positive effects of plants on indoor climate.

On whether occupants were satisfied with their personalisation possibilities, almost $40 \%$ of the occupants in CAP were less satisfied. In the airconditioned buildings, averagely $20 \%$ of the respondents were not satisfied with their personalisation possibilities. Fifty percent of the workers asked in DCD were also not satisfied. This was because of the nature of the shared offices which were not spacious enough to accommodate the three and sometimes four workers. The higher dissatisfaction with workspace personalisation possibilities correlates with the general feeling of poor indoor climate. This also means that the higher the satisfaction, the more positive the office climate. This is a clue which needs further study by widening the scope of buildings and occupants to make this assertion statistically significant.

Asked about their view on the most important features of an ideal working place, the respondents in building CAP voted air quality, comfort of furnishings, dimensioning of workspace, and thermal comfort as most important (see Tables 4 and 5). Lambeva (2007) also found improvement in office furniture to be part of the most urgent measures needing improvement in a similar study on an office building in Austria. This shows the importance of ergonomic furniture to occupants by virtue of the nature of their responsibilities in office buildings.

The least important features were acoustic comfort, fire safety, and aesthetics of the building. Aesthetics of the building not being rated as important is understandable. The ranking on the other buildings were similar to the ratings at CAP.
In Fig. 10, the most urgent improvement measures for all the buildings are presented. The most urgent measure was air quality. In mixed mode and naturally ventilated buildings, dusty northeast trade winds during the dry season could be the main factor leading to dissatisfaction. In air-conditioned buildings, users might have been able to rely on their control systems and thereby creating exclusive indoor environments (Hawkes, 1996). A possible aspect might also be the inefficiency of air-conditioners, leading to poor ventilation qualities. Factors on ventilation quality are: air cleanliness, appropriate air temperature range, adequate volumetric airflow rates and comfortable air velocities around occupants (Heerwagen, 2004). These factors could be linked to thermal comfort as a second measure needing attention. The temperatures were higher in the workspaces, above $27^{\circ} \mathrm{C}$ in the air-conditioned buildings due to multiple factors. The buildings were not optimally oriented, lacked shading devices and did not make use of natural ventilation when outdoor air was cool. Also, the higher levels of infiltration through the inappropriate windows worsened the situation. In addition, airconditioned buildings need to have compact forms, be protected from rising moisture and water vapour diffusion and openings should be as small as possible (Lauber, 2005). These principles should be given attention to when designing and constructing air-conditioned buildings.

At ROY, exposed glazing was used on the building envelope and as a recommendation, more efficient glazing should be used, which has to be shaded in order to have positive effects on energy conservation and on the thermal environment (Wagner et al., 1980 and Kiang et al., 2000). This calls for sustainable design practices during the design, construction and arrangement stages of the workspaces.

With the exception of few workspaces where furnishings were comfortable and spacious, most occupants had to share offices and use non-ergonomic furniture. Moreover, there were 
few breakaway zones in the office spaces and all these factors tend to make occupants dissatisfied. The contribution of worker satisfaction and comfort to productivity seemed not to be exploited and managers need to make sure building occupants feel comfortable in their workspaces. This calls for routine maintenance and feedback from occupants on workspace environment.

Fire safety, visual comfort, security against theft and acoustic comfort followed the rank of measures needing attention. During the study period, several fire accidents had happened in the city and this might have contributed to the rating on fire safety. Nevertheless, fire extinguishers were seen only in few areas of all the buildings. The malfunctioning and nonavailability of shading devices contributed to visual problems through reflections and glare. Additionally, glare is known to have a direct relation to the operation of window shades and workspace organization (Lindsay and Littlefair, 1992). However, day lighting is known to provide minimal veiling reflections, excellent vertical surface illumination, and visual interest among other advantages. As a result, numerous studies have conclusively demonstrated that day lighting is a marked preference over any form of lighting (Stein and Reynolds, 2000).

The last three features of improvement measures considered most urgent were liberty to control one's own environment, acoustic and visual privacy, and beauty/aesthetics of the building. Acoustic and visual privacy being rated not urgent was a surprise. It was anticipated that the shared offices with the associated noise would significantly disturb the occupants and that they would have opted for more privacy. However, as a design recommendation in office spaces, floors are to be carpeted in order to drastically reduce the sound of chair movements (Stein and Reynolds, 2000).

Provided the environment is comfortable, occupants would not mind if someone else controlled their workspace climate. However, in the course of the interviews, the desire to have access and operate flexible building systems was found to be important for the occupants, as it increased their satisfaction levels in the workspaces. This correlates with the finding that satisfaction increases when there is a great flexibility in the operation of building systems (Lechner, 2001).

Aesthetics of the building was the least urgent measure and this was understandable since numerous measures needed to be resolved within the building. Probably, occupants might consider beauty of the building when they are satisfied with their workspaces.

\section{CONCLUSION}

Occupants in office buildings found it important to be able to operate windows. This seems to be a basic desire, which must be considered and provided, especially in curtain wall and airconditioned buildings. The results of the study correlate with the general knowledge that satisfaction increases when there is great flexibility in the operation of building systems and workspace personalization. These systems must be easily made available, accessible and easy to operate since with more personal control, workers express feelings of comfort. Building owners and facility managers must use remote controls or on-screen operation systems to make it easier to operate building systems. In addition, intelligent system controllers have to be installed in new and retrofitted buildings to improve workspace satisfaction. This calls for training in the right use of the operation and accessibility of building systems and system controls to enhance satisfaction and comfort in office environments. By cultivating sustainable design principles, most problems associated with thermal and visual comfort could be solved, and designers are hereby advised to urgently consider this important practice.

\section{REFERENCES}

Fanger, P. O. (1973). Thermal Comfort, McGraw Hill Book Company, New York. 
Givoni, B. (1976). Man, Climate and Architecture, Second Edition, Van Nostrand Reinhold Company, New York, USA.

Gut, P. and Ackerknecht, D. (1993). Climate Responsive Building, First Edition, SKAT - Swiss Centre for Development and Cooperation in Technology and Management, Switzerland.

Hawkes, D. (1996). The Environmental Tradition - Studies in the Architecture of Environment, E and FN SPON, London.

Heerwagen, D. (2004). Passive and Active Environmental Controls: Informing the Schematic Designing of Buildings, First Edition, McGraw Hill, New York, USA.

Herkel, S., Knapp, U. and Pfafferott, J. (2005). A Preliminary Model of User Behaviour Regarding the Manual Control of Windows in Office Buildings. In I. BeausoleilMorrison \& M. Bernier (eds.), Ninth In ternational IBPSA Conference, Building Simulation 2005. Montréal, Canada, 1518 August.

Hyde, R. (2000). Climate Responsive Design, First Edition, E \& FN Spon, United Kingdom.

Kiang, P. S., Feriadi, H., Biao, W. J. and Batia, S. (2000). Evaluation of Energy Perform ance Using Doe-2 Energy Simulation Programme in Singapore, Dimensi Teknik Arsitektur, 28 (2): 147 - 154.

Koranteng, C., Mahdavi, A., Orehounig, C. and Pröglhof, C. (2009). Thermal Perform ance of Office Buildings in Ghana, In: Proceedings of the $11^{\text {th }}$ International IB PSA Conference, on Building Simulation, held in Glasgow, Scotland, 27 - 30 July, 2009.

Lambeva, S. L. (2007). User Interaction with Environmental Control Systems in an
Educational Office Building, Ph.D., Tech nology University of Vienna, Austria.

Lauber, W. (2005). Tropical Architecture, First Edition, Prestel Verlag, Munich, Germany.

Lechner, N. (2001). Heating, Cooling, Lighting: Design Methods for Architects, Second Edition, John Wiley \& Sons, Inc., New York, USA.

Lindsay, C. T. R. and Littlefair, P. J. (1992). Oc cupant Use of Venetian Blinds in Offices, Building and Research Establishment (BRE), Contract PD233/92, Gartson Library, Watford, UK.

Loftness, V., Hartkopf, V., Shankavaram, J. and Mahdavi, A. (1995). User-Based Control Choices in Relation to Thermal Comfort, Air Quality and Energy Conservation in Buildings, Center for Building Studies, Concordia University, Canada.

Mohammadi, A. (2007). Modeling Occupants' Control Actions and their Energy Implications in an Office Building, Ph.D., Technology. University of Vienna, Austria.

Mokamelkhah, E. K. (2007). Lighting, Shading and Ventilation Controls: A Study of User Behaviour in Office Buildings, Ph.D., Technology University of Vienna, Austria.

Mahdavi, A., Mohammadi, A., Kabir, E. and Lambeva, L. (2007). User Control Actions in Buildings: Patterns and Impact, Well Being Indoors, Clima 2007 Conference, 10 - 14 June, Helsinki, Finland, Seppänen O, Säteri J, (Ed.), ISBN: 978-952-99898-2 -9, Paper-No. C03.

Nicol, F. J. (2001). Characterising Occupant Behaviour in Buildings: Towards a Stochastic Model of Occupant Use of Windows, Lights, Blinds, Heaters and Fans, 
Evaluation of Occupants' Behaviour and Preferences in Office Buildings...

Seventh International IBPSA Conference, Rio de Janeiro, Brazil, 13 - 15 August.

Nicol, F. and Roaf, S. (2005). Post-occupancy Evaluation and Field Studies of Thermal Comfort, Building Research and Information, 33 (4): 338 - 349. Ocr. (2008). On set Computer Corporation, www.onsetcomp.com, Accessed: October 20, 2008

Rijal, H. B., Tuohy, P., Humphreys, M. A., Nicol, J.F., Samuel, A., Raja, I.A. and Clarke, J. (2008). Development of Adaptive Algorithms for the Operation of Windows, Fans and Doors to Predict Thermal Comfort and Energy Use in Pakistani Buildings, ASHRAE Transactions, USA.

Salmon, C. (1999). Architectural Design for Tropical Regions, First Edition, John
Wiley \& Sons, Inc., New York, USA.

Stein, B. and Reynolds, J. S. (2000). Mechani cal and Electrical Equipment for Build ings, Ninth Edition, John Wiley \& Sons, Inc., New York, USA.

Sutter, Y., Dumortier D. and Fontoynont, M. (2006). The Use of Shading Systems in VDU Task Offices: A Pilot Study, Energy and Buildings, 38 (7): 780 - 789.

Wagner, W., Robinson, J. and Markert, P. (1980). Energy-Efficient Buildings, First Edition, McGraw-Hill Book Company, New York, USA.

Watson, D. and Labs, K. (1983). Climatic Design: Energy-Efficient Building Principles and Practices, First Edition, McGraw-Hill Book Company, New York, USA. 